\title{
Arguing With Law: Strategic Legal Argumentation, US Diplomacy and Debates Over the International Criminal Court
}

\author{
ADAM BOWER ${ }^{1}$ \\ adam.bower@politics.ox.ac.uk
}

Abstract. Recent studies have highlighted the instrumental use of language, wherein actors deploy claims to strategically pursue policy goals in the absence of persuasion or socialization. Yet these accounts are insufficiently attentive to the social context in which an audience assesses and responds to strategic appeals. I present a theoretical account that highlights the distinctly powerful role of international law in framing strategic argumentation. Legalized discourses are especially legitimate because law is premised on a set of internally coherent practices that constitute actors and forms of action. I then illustrate the implications in a hard case concerning US efforts to secure immunities from International Criminal Court jurisdiction. Contrary to realist accounts of law as a tool of the powerful, I show that both pro- and anti-ICC diplomacy was channelled through a legal lens that imposed substantial constraints on the pursuit of policy objectives. Court proponents responded to US diplomatic pressure with their own legal arguments; this narrowed the scope of the exemptions, even as the Security Council temporarily conceded to US demands. While the US sought to marry coercion with argumentative appeals, it failed to generate a lasting change in global practice concerning ICC jurisdiction.

Adam Bower is a Social Sciences and Humanities Research Council of Canada Postdoctoral Fellow at the Department of Politics and International Relations, University of Oxford and a Research Fellow at Nuffield College. His research focuses on the interaction of international law and politics, and is especially concerned with assessing the implementation and impact of legal institutions in the fields of disarmament and international humanitarian and criminal law.

\footnotetext{
${ }^{1}$ For constructive feedback that greatly improved the content and presentation of this article I thank Gregorio Bettiza, Michael Byers, Katharina Coleman, Brad Epperly, Ryder McKeown, Richard Price and the anonymous reviewers. Any remaining errors of course are my responsibility alone. I also gratefully acknowledge financial and institutional support from the Social Sciences and Humanities Research Council of Canada, the Department of Politics at the University of British Columbia, the Max Weber Programme at the European University Institute, and the Department of Politics and International Relations and Nuffield College, Oxford.
} 


\section{Introduction}

The field of International Relations has become increasingly occupied with the role of language in world politics. Important contributions by rationalist scholars emphasizing the calculated deployment of rhetoric ${ }^{2}$ and communicative accounts that highlight the truth-seeking and consensus-building purpose of argumentation ${ }^{3}$ have sought to clarify the various logics and effects of speech acts. This article further attends to this discussion through a focused investigation of the role of legal rhetoric in international diplomacy. To do so, it proposes a theoretical conception of strategic argumentation through law. Following recent studies, ${ }^{4} \mathrm{I}$ contend that many international debates can be conceptualized as strategic interactions, wherein actors deploy various claims in an attempt to compel other participants to accept their proposed policy. This account does not assume that actors enter into debates with the expectation of altering their own underlying preferences, or that successful outcomes require such change in others. While participants would prefer to persuade their interlocutors to change their views and endorse a given approach (since this would result in a more stable outcome), they are content in the short term to use reasoned arguments to shift the political terrain such that competing claims — and the attendant policies — are no longer regarded as politically advantageous. In this case, it is not necessary for all actors to genuinely agree with the stated policy, but simply to be

\footnotetext{
${ }^{2}$ Frank Schimmelfennig, 'The Community Trap: Liberal Norms, Rhetorical Action, and the Eastern Enlargement of the European Union', International Organization, 55:1 (2001), pp. 4780 .

${ }^{3}$ Nicole Deitelhoff and Harald Müller, 'Theoretical Paradise - Empirically Lost? Arguing with Habermas', Review of International Studies, 31:1 (2005), pp. 167-79; Roger A. Payne, 'Persuasion, Frames and Norm Construction', European Journal of International Relations, 7:1 (2001), pp. 37-61; Thomas Risse, "'Let’s Argue!": Communicative Action in World Politics,' International Organization, 54:1 (2000), pp. 1-39.

${ }^{4}$ Ronald R. Krebs and Patrick Thaddeus Jackson, 'Twisting Tongues and Twisting Arms: The Power of Political Rhetoric', European Journal of International Relations, 13:1 (2007), pp. 3566.
} 
given sufficient grounds on which to concede the point and adapt their behaviour to meet the other side's demands. This account is therefore sensitive to the methodological challenges inherent in studying cognitive changes that underpin accounts of persuasion. ${ }^{5}$

Yet even the self-interested employment of rhetoric requires an audience to assess and respond to competing claims and in this way, my account shares assumptions from the constructivist literature concerning the intersubjective basis for effective arguing. ${ }^{6}$ Actors seeking to generate acceptance, if not genuine endorsement, of their views cannot employ just any claim at random, but must instead frame their arguments within recognized boundaries. Hence, even strategic argumentation, and the tactical concessions it seeks to compel, is rooted in shared understandings that provide a framework for determining the more compelling claim. The social setting in which rhetorical contestation occurs thus provides structural constraints that limit the range of claims that will be considered acceptable to the wider audience.

Accounts of rhetorical action and coercion have acknowledged the necessary role of audience dynamics, but have left the description of its substance underdeveloped. Elaborating on recent constructivist accounts, I contend that the social structure of international law provides the basis for a shared environment in which strategic argumentation may take place. ${ }^{7}$ Law is defined

\footnotetext{
${ }^{5}$ Ibid.; Tine Hanrieder, 'The False Promise of the Better Argument', International Theory, 3:3 (2011), pp. 390-415.

${ }^{6}$ Deitelhoff and Müller, 'Theoretical Paradise - Empirically Lost?'; Harald Müller, 'Arguing, Bargaining and All That: Communicative Action, Rationalist Theory and the Logic of Appropriateness in International Relations,' European Journal of International Relations, 10:3 (2004), pp. 395-435; Payne, 'Persuasion, Frames and Norm Construction'; Risse, '"Let's Argue!"'.

${ }^{7}$ Jutta Brunnée and Stephen J. Toope, Legitimacy and Legality in International Law: An Interactional Account (Cambridge; New York: Cambridge University Press, 2010); Jutta Brunnée and Stephen J. Toope, 'Constructivism and International Law', in Jeffrey L. Dunoff and Mark A. Pollack (eds.), Interdisciplinary Perspectives on International Law and International Relations: The State of the Art (Cambridge: Cambridge University Press, 2013), pp. 119-45; Martha J. Finnemore and Stephen Toope, 'Alternatives to Legalization: Richer Views of Law and
} 
by an internal logic of justification based in precedent that constitutes actors and appropriate forms of action. When actors argue via legal means they seek to validate particular behaviours or policies as conforming to, or violating, established principles, rules and norms that are bound up in the practice of legality. These can be distinguished from, and are intersubjectively recognized as superior to, more politicized forms of rhetoric that explicitly invoke self-interest to the general exclusion of principled justifications. ${ }^{8}$ In sum, strategic argumentation seeks to gain acceptance for a particular policy goal from other relevant actors by invoking claims that are mutually comprehensible. Legal arguments are especially powerful in such contests because they are connected to the social construction of international society, and therefore represent an especially legitimate source of justification.

This account of strategic legal argumentation has two specific implications. First, in multilateral settings actors will tend to invoke justifications based in legal principles, norms and rules - potentially in conjunction with coercive efforts - in pursuing policy goals. This strategy is preferable even when the actor making a claim does not fully endorse the standards it employs. Yet due to the particular discursive structure and authority of international law, even the cynical invocation of law can impose important limitations on freedom of action, by narrowing the scope of future argumentation and making actions subject to retrospective assessment on the basis of these prior claims. States may then become rhetorically entrapped and face politically consequential challenges linked to factual disputes (challenges regarding their interpretation of

Politics', International Organization, 55:3 (2001), pp. 743-58; Christian Reus-Smit, 'Politics and International Legal Obligation', European Journal of International Relations, 9:4 (2003), pp. 591-625.

${ }^{8}$ Christian Reus-Smit, 'The Politics of International Law', in Christian Reus-Smit (ed.), The Politics of International Law (Cambridge: Cambridge University Press, 2004), pp. 14-44; Shirley V. Scott and Olivia Ambler, 'Does Legality Really Matter? Accounting for the Decline in US Foreign Policy Legitimacy Following the 2003 Invasion of Iraq', European Journal of International Relations, 13:1 (2007), 67-87. 
the law) or claims of hypocrisy (not upholding their purported commitments). Under these circumstances, resistance from the target audience can increase the costs of a proposed policy leading to its abandonment. ${ }^{9}$ Second, legal discourses provide a reservoir of meaning which less materially powerful actors can exploit to challenge dominant states and promote their own policy goals. Arguing via law entails a transformation of power into a social commodity wherein material capabilities are wedded to, and altered by, forms of legitimating power to produce outcomes. ${ }^{10}$ This account therefore challenges realist conceptions of law in which preponderantly powerful states merely use legal institutions to pursue their own self-interested goals while remaining essentially immune from legal constraints not to their liking. ${ }^{11}$

I illustrate these theoretical claims with close attention to a series of diplomatic efforts by the United States to challenge the scope of International Criminal Court (ICC) jurisdiction at the United Nations Security Council (UNSC). From its inception, the ICC was the subject of a wideranging and aggressive US campaign to secure special exemptions from the ICC's criminal accountability regime. Proponents of an independent Court sought to resist US demands without recourse to parallel threats or incentives, but instead through the force of argument. On its face, this latter strategy would appear unpromising, as prominent theories of International Relations hold that preponderantly powerful actors will leverage their military and economic advantages to assert their will in the international system. Indeed, given the degree of its opposition, the ICC

\footnotetext{
${ }^{9}$ Thomas Risse, Stephen C. Ropp, and Kathryn Sikkink (eds.), The Power of Human Rights: International Norms and Domestic Change (New York: Cambridge University Press, 1999); Heather Smith-Cannoy, Insincere Commitments: Human Rights Treaties, Abusive States, and Citizen Activism (Washington, DC: Georgetown University Press, 2012).

${ }^{10}$ Michael Barnett and Raymond Duvall, 'Power in International Politics', International Organization, 59:1 (2005), pp. 39-75.

${ }^{11}$ Michael J. Glennon, Limits of Law, Prerogatives of Power: Interventionism after Kosovo (New York: Palgrave, 2001); Jack L Goldsmith and Eric A Posner, The Limits of International Law (New York: Oxford University Press, 2005).
} 
would seem like a case where the United States was most likely to contest — and ideally

reverse - the reach of the new institution; the use of reasoned discourse to counteract this threat should have little impact when confronted with such material disparities. Assessing the impact of legal claim making under these challenging conditions thus provides a strong test of my account of strategic legal argumentation and policy change.

Despite these apparent impediments, pro- and anti-ICC diplomacy was channelled through a legal lens that imposed substantial constraints on the pursuit of policy objectives. Both the ICC's most prominent detractor and its proponents employed a variety of claims concerning specific ICC rules and broader principles of international law in support of their preferred interpretation of the Court's prospective jurisdiction over nationals of non-party states. While the US retained forms of coercion, they were tempered by a rhetorical strategy that sought to justify American policy within the specific parameters of international legal practice and the rules of an institution it openly rejected. Yet the decision to pursue a legal mode of justification exposed US claims to unfavourable assessment as both factually incorrect and hypocritical. In the face of sustained pressure, ICC parties were able to assemble an alternative narrative that joined technical legal interpretations with a set of claims concerning the appropriate conduct within the international legal order. In the short term this had the effect of substantially narrowing the scope of the special exemptions, even as the Security Council temporarily conceded to US demands. In the longer term, however, the US position proved socially unsustainable. The United States was therefore unable to leverage its superior political, military and economic capabilities to generate a lasting acceptance of its claim to ICC immunities.

My most fundamental contention, therefore, is that the invocation of legal claims tempers and constrains the use of coercive tactics such that the deployment of material power resources 
has different—and more modest—effects than it would in a non-argumentative and especially non-legal setting. Indeed, US actions have paradoxically reinforced the ICC through a process of legal claim making that was intended to do the exact reverse. Hence the US pursuit of its interests had unintended consequences precisely due to the way in which international social meaning is generated via legal argumentation. In this way, the present article takes up Brunnée and Toope's call for scholars to "focus more attention on empirical studies that illustrate the distinctiveness of law... and that explore how that distinctiveness plays out in specific contexts and issue areas." ${ }^{12}$ In so doing, the article makes two principal theoretical contributions. On the one hand, it furthers the integration of instrumental and norm-based logics, by showing how the strategic use of principled arguments interacts with material forces to affect policy outcomes. On the other hand, it attends to an ongoing debate among International Relations and International Law scholars, by providing further evidence regarding the means through which international law serves as a source of legitimate authority in real-world settings ${ }^{13}$ Finally, the article provides empirical detail to uncover the practical consequences of diplomacy — and the status of a key feature of the ICC's legal regime — under conditions of great power resistance.

\title{
Strategic Action, Audiences and Argumentation in World Politics
}

\author{
Defining Strategic Argumentation
}

\footnotetext{
${ }^{12}$ Brunnée and Toope, 'Constructivism and International Law,' p. 139.

${ }^{13}$ Brunnée and Toope, Legitimacy and Legality in International Law; Ian Johnstone, The Power of Deliberation: International Law, Politics and Organizations (New York: Oxford University Press, 2011); Steven R. Ratner, 'Persuading to Comply: On the Development and Avoidance of Legal Argumentation', in Jeffrey L. Dunoff and Mark A. Pollack (eds.), Interdisciplinary Perspectives on International Law and International Relations: The State of the Art (Cambridge: Cambridge University Press, 2013), pp. 568-90; Reus-Smit, 'Politics and International Legal Obligation'; Scott and Ambler, 'Does Legality Really Matter?'.
} 
Arguing is central to political life in both domestic and international societies. I employ a common sense definition of arguing as the use of reasons — whether verbal or written — to justify a particular policy to a target audience, with the intention of causing these actors to alter their behaviour accordingly. Yet my approach differs from the most common usage in IR by relaxing the assumption that arguing implies a change in the beliefs or opinions of audience members. Scholars of communicative action contend that argumentative rationality is premised on the creation of shared understandings in which actors must be open to changing their own views on the basis of a better argument. ${ }^{14}$ Instead, I propose a conception of strategic argumentation in which persuasion and socialization is not necessary to generate meaningful change in international outcomes. While actors would prefer to change the minds of their target audiencesince this would result in a more lasting solution in their favour-in the short term the purpose can be to shift the strategic terrain such that other arguments are no longer sustainable.

In this form of rhetorical contestation, two or more parties present competing claims concerning a purported problem and a policy solution that follows from their framing. The goal is to deploy arguments that are acceptable to the wider audience of participating actors and in that way deny the opposing claimant(s) equally suitable rhetorical grounds for continuing the debate. Hence, "winning" an argument on these terms does not require a fundamental shift in actor identities or preferences, but can more simply be achieved if the other side determines that it is no longer worth continuing the contest, and alters its behaviour in order to meet the demands of its interlocutor. The "losing" side may not have been persuaded of the validity of its

${ }^{14}$ Deitelhoff and Müller, 'Theoretical Paradise - Empirically Lost?'; Johnstone, The Power of Deliberation; Müller, 'Arguing, Bargaining and All That'; Ratner, 'Persuading to Comply'; Risse, "'Let's Argue!". 
opponent's argument, but acquiesces to the policy demand so as to avoid audience sanctions or the sheer cost of further argumentation. ${ }^{15}$

My account is closely related to existing conceptions of "rhetorical action" and "rhetorical coercion,"16 though I prefer the term strategic argumentation. This retains the focus on the deliberate and self-interested use of language to achieve policy goals, and does not seek to account for changes in cognitive beliefs of states, bureaucratic organizations or individual human subjects. At the same time, the explicit reference to arguing draws attention to the salience of principled claims at the root of strategic action. Argumentation — whether meeting the conditions of genuine deliberation or not—is based in factual statements about how the world works, or normative claims concerning what should be done. It is also interactive, as members of the target audience will respond with their own reasoned claims. Legitimate international authority is ultimately sustained as much by intersubjective justification as by the raw application of force. The present account thus shares the assumption of communicative action that the valorization of reasoned claims leads to a diminishment of material power resources that characterize bargaining and coercion. ${ }^{17}$ And while argumentation assumes that all aspects of discourse are open to contestation, the ability to advance claims, and respond to those proposed by others, requires at least some minimum degree of stability in the underlying social structure. The meaning of social norms and legal rules is never fully solidified, though to the extent that they bear upon actors at a particular moment in time, institutions may be studied as effectively fixed entities. ${ }^{18}$

\footnotetext{
${ }^{15}$ Krebs and Jackson, 'Twisting Tongues and Twisting Arms,' pp. 43-45; Schimmelfennig, 'The Community Trap,' p. 64.

${ }^{16}$ Schimmelfennig, 'The Community Trap'; Krebs and Jackson, 'Twisting Tongues and Twisting Arms.'

${ }^{17}$ Müller, 'Arguing, Bargaining and All That', p. 397; Risse, "'Let's Argue!"', p 9.

${ }^{18}$ Benjamin R. Banta, 'Analysing Discourse as a Causal Mechanism', European Journal of International Relations, 19:2 (2013), p. 390.
} 
For these reasons, the public language of diplomacy is causally significant for outcomes in world politics irrespective of the internal dispositions of subject actors. ${ }^{19}$ Whether actors are fundamentally transformed by argumentative practices, their actions are conditioned by the social setting in which both calculated use of rhetoric and genuine truth-seeking take place. This insight generates theoretical expectations concerning the consequences of public utterances that can be traced in the empirical record. Both rationalist and constructivist scholars have highlighted potential audience costs when actors violate their own previously articulated standards; these may take the form of material sanctions, or social rewards and punishments tied to status within a community. ${ }^{20}$ In my account, the deployment of strategic argumentation can lead actors to become rhetorically entrapped by a more effective alternative frame, and concede to the will of their opponent by dropping the argument and revising their behaviour accordingly. Regardless of the motivations, therefore, the credibility and consistency of claims bears upon their reception and the perceived legitimacy of associated policies.

\section{Audience Dynamics and the Impact of Claims}

Diplomacy takes place via justificatory discourse, and in this way implicates some audience of other actors in the deployment and reception of claims. This is made explicit in accounts of communicative action, but strategic environments are also underpinned by a social setting in which rhetorical contests can be adjudicated. Instrumental theories of compliance acknowledge that actors reside within a community of similarly-situated others, and that the constitutive norms

\footnotetext{
${ }^{19}$ Banta, 'Analysing Discourse as a Causal Mechanism'; Krebs and Jackson, 'Twisting Tongues and Twisting Arms.'

${ }^{20}$ Andrew T. Guzman, How International Law Works: A Rational Choice Theory (Oxford; New York: Oxford University Press, 2008); Johnstone, The Power of Deliberation; Ratner, 'Persuading to Comply'; Risse, Ropp, and Sikkink, The Power of Human Rights; Schimmelfennig, 'The Community Trap'.
} 
of this community inform - but do not strictly determine - the self-interested pursuit of policy goals. ${ }^{21}$ More specifically, since meanings in the international system cannot be imposed unilaterally, models of rhetorical action presume that target subjects must accept or reject the proposed arguments. ${ }^{22}$ As a practical matter, therefore, actors must be attentive to the content of their claims, and seek to tie their particular appeals to widely recognized community standards since this will increase the chances of their argument being accepted. Collectively held views concerning the appropriateness of certain discourses and behaviours thus strongly condition and constrain the type of claims that actors may make in legitimating their policies.

Yet this still leaves open the vital question of why some arguments resonate more effectively with an audience. The instrumental accounts surveyed above do not offer much insight into how the specific content of claims should impact upon their reception beyond the general conclusion that the quality of arguments matters. For Schimmelfennig, actors deploy arguments in view of a general "standard of legitimacy" in which the most valid arguments are those that are deemed to most closely adhere to the accepted normative structure of values and beliefs. ${ }^{23}$ Krebs and Jackson employ a minimal conception in which an argument "wins" when “its grounds are socially sustainable — because the audience deems certain rhetorical deployments acceptable and others impermissible."24 But neither explanation gets to the bottom of the content of these necessary determinations and why certain arguments are judged to be better in the first place - or, to put it differently, what constitutes the prevailing standard of legitimacy which may be acted upon. I contend that we can provide greater precision in accounts

${ }^{21}$ Guzman, How International Law Works; Schimmelfennig, 'The Community Trap'.

${ }^{22}$ Krebs and Jackson, 'Twisting Tongues and Twisting Arms', p. 45.

${ }^{23}$ Schimmelfennig, 'The Community Trap', p. 63.

${ }^{24}$ Krebs and Jackson, 'Twisting Tongues and Twisting Arms', p. 47. 
of rhetoric and argumentation by drawing attention to the particular role of international law as an authoritative source of claims in the international community of states.

\section{Strategic Argumentation Through International Law}

The assertion that international law serves as a primary source of legitimate authority in the international system is not novel, as legal scholars have long recognized. ${ }^{25}$ However, international law as a field academic inquiry has tended to emphasize the formal doctrinal sources of law and has consequently been less inclined to reflect on the social origins of the legitimacy — and hence obligatory status - that law is said to command. ${ }^{26}$ Despite extensive efforts at bridge building, IR scholars have been slow to capitalize on these insights. ${ }^{27}$ Law is understood to be distinct from-yet related to - other ideational phenomena like social norms or moral values and material forces like military or economic capacity. Yet the relationship to the substantive context of argumentation, and hence the particular difference that legal discourses are expected to make in comparison to other forms of agency, is often under-specified. ${ }^{28}$

\footnotetext{
${ }^{25}$ For a classic statement see Thomas M. Franck, The Power of Legitimacy Among Nations (New York: Oxford University Press, 1990). More recently see Michael Byers, Custom, Power and the Power of Rules: International Relations and Customary International Law (Cambridge: Cambridge University Press, 1999). Legal scholars have also explored the enactment of legal argumentation and interpretation in a variety of settings. See for example Ian Johnstone, 'Security Council Deliberations: The Power of the Better Argument', European Journal of International Law, 14:3 (2003), pp. 437-80; and Steven R. Ratner, 'Does International Law Matter in Preventing Ethnic Conflict?', New York University Journal of International Law and Politics, 32:3 (2000), pp. 591-698.

${ }^{26}$ Michael Byers, 'International Law', in Christian Reus-Smit and Duncal Snidal (eds.), The Oxford Handbook of International Relations (Oxford; New York: Oxford University Press, 2008), p. 613; Reus-Smit, 'Politics and International Legal Obligation'.

${ }^{27}$ For recent overviews see Emilie M. Hafner-Burton, David G. Victor, and Yonatan Lupu, 'Political Science Research on International Law: The State of the Field', The American Journal of International Law, 106:1 (2012), pp. 47-97; and Byers, 'International Law'.

${ }^{28}$ Ratner, 'Persuading to Comply', p. 572.
} 
Following recent constructivist accounts, ${ }^{29} \mathrm{I}$ contend that legal institutions represent a powerful source of authority in the international system because law is intimately bound up in the social construction of international actors and acceptable forms of action. The structure of legal reasoning thus provides the necessary shared expectations that underpin both communicative/deliberative and strategic/instrumental forms of arguing.

\section{The Social Structure of International Law as a Reservoir of Legitimacy}

Constructivist IR theory has made significant contributions in conceptualizing international law as part of a multifaceted social system. In this account, law is not defined by a by a strictly enumerated set of binding rules backed by sanctions - as per rationalist "hard law" approaches ${ }^{30}$ — but rather encompasses a particular mode of practice based in precedent that generates categories of meaning and more specific permissive and prohibitionary standards. International law's essence is rooted in a principled justificatory discourse that channels present debates over the meaning and scope of law through reference to previously articulated rules and procedures. ${ }^{31}$ In so doing, actors engage in a continual process of making and evaluating claims concerning the prescriptive and proscriptive status of law. These associated repertoires of ideas,

${ }^{29}$ Brunnée and Toope, Legitimacy and Legality in International Law; Finnemore and Toope, 'Alternatives to Legalization'; Reus-Smit, 'Politics and International Legal Obligation'; Christian Reus-Smit (ed.), The Politics of International Law (Cambridge: Cambridge University Press, 2004).

${ }^{30}$ Kenneth W. Abbott et al., 'The Concept of Legalization,' International Organization, 54:3 (2000), pp. 401-20; Alexander Thompson, 'Coercive Enforcement of International Law', in Jeffrey L. Dunoff and Mark A. Pollack (eds.), Interdisciplinary Perspectives on International Law and International Relations: The State of the Art (Cambridge: Cambridge University Press, 2013), pp. 502-23.

${ }^{31}$ Johnstone, The Power of Deliberation; Ratner, 'Persuading to Comply'. 
behaviours and language comprise the intersubjective practices that structure international legal action, and aggregate over time as precedents that increasingly bind participants to positions. ${ }^{32}$

The development and enactment of international law is thus intimately associated with the social construction of international actors and the definition of acceptable and unacceptable forms of action. A central insight of recent constructivist work is that "legal practices are embedded within, and constituted by, layers of nested social understandings." ${ }^{33}$ The authoritative nature of law is derived from its connection to fundamental normative structures that act as ordering principles to demarcate the constituent units of the system and structure subsequent efforts to develop frameworks for appropriate conduct. In the contemporary international system, conceptions of territorially based sovereign statehood, contractual international law, the sanctity of commitments (pacta sunt servanda) and multilateral diplomacy operate both as a precondition for mutual recognition and foundational rules of the game through which actors pursue their policy goals. ${ }^{34}$ In turn, they provide the impetus for the development of particular normative systems that constitute the features of "responsible" statehood—defining acceptable behaviour in issues such as the conduct of warfare, the nature of human rights and proper representation in political communities - that may be further articulated as more precise norms and rules.

This social density explains why actors to regard law as an especially legitimate form of order and, consequently, how a generalized obligation towards the law develops. Legal institutions emerge from the intersubjective practices of actors and are thereby nested within the

\footnotetext{
${ }^{32}$ Emanuel Adler and Vincent Pouliot, 'International Practices', International Theory, 3:1 (2011), pp. 1-36.

${ }^{33}$ Christian Reus-Smit, 'Obligation through Practice', International Theory, 3:2 (2011), p. 344.

${ }^{34}$ Christian Reus-Smit, 'The Constitutional Structure of International Society and the Nature of Fundamental Institutions', International Organization, 51:4 (1997), pp. 555-89; Friedrich V. Kratochwil, Rules, Norms, and Decisions: On the Conditions of Practical and Legal Reasoning in International Relations and Domestic Affairs (Cambridge University Press, 1989).
} 
underlying normative structure of the system. ${ }^{35}$ While the resort to law is undoubtedly driven in part by the desire of state actors to advance self-interested goals like improving organizational efficiency, bolstering reputation or exerting their will, these considerations are given meaning by a pre-existing belief that the international legal system possesses legitimate authority worthy of adherence. ${ }^{36}$ In this way, legal institutions contribute to the reconstruction of actor interests and subsequent behaviours, meaning that "politics may take a distinctive form when conducted within the realm of legal reasoning and practice."37

Conceiving of law as a core feature of the international social system suggests how the shared understandings essential to effective argumentation action may develop among selfinterested actors. Schimmelfennig and Krebs and Jackson recognize that the social legitimacy of claims is central to their reception and hence, impact, but do not extensively develop this important point. I contend that since international law helps to constitute international politics, it comprises an authoritative source of collective validity claims and a basic grammar "in which speakers anchor their arguments. ${ }^{38}$ Actors may not agree about the fundamental correctness of specific claims — which is not necessary in a strategic account—-but the resort to legal argument provides a shared language for determining the minimal acceptability of competing positions. One key consequence is that while politics and law are co-constituted, actors regard the international legal realm as a partially autonomous field of action in which different ground rules apply. ${ }^{39}$ Legal discourses can be distinguished from political forms of argumentation by the fact

\footnotetext{
${ }^{35}$ Brunnée and Toope, Legitimacy and Legality in International Law; Reus-Smit, 'Politics and International Legal Obligation'; Reus-Smit, 'Obligation through Practice'.

${ }^{36}$ Reus-Smit, 'Politics and International Legal Obligation', p. 613.

${ }^{37}$ Reus-Smit, 'The Politics of International Law', p. 14.

${ }^{38}$ Deitelhoff and Müller, 'Theoretical Paradise - Empirically Lost?', p. 172.

${ }^{39}$ Reus-Smit, 'The Politics of International Law', pp. 36-37; Scott and Ambler, 'Does Legality Really Matter?'.
} 
that the former are framed in the context of agreed standards informed by precedent while the latter tend to invoke more transitory concerns for self-interest (what benefits a given party in the particular situation) unencumbered by principled justification. For these reasons, law is typically held to be more technocratic and impartial in contrast to an unregulated political realm in which material power is expected to dominate. ${ }^{40}$ Of course law is never truly divorced from power, as dominant actors create and interpret legal institutions in the pursuit of their own egoistic policy preferences. ${ }^{41}$ Yet while profoundly shaped by material realities, a transition to a legalized mode of justification channels and moderates these forces through a particular social process that is generally regarded as more legitimate in its application and adjudication. For this reason, "[w] hen an actor in world politics makes reference to international law he or she is implying that international law offers the highest standard against which action in world politics can be judged; if offering an argument based on international law it is a justification 'other than' or 'more than' a mere political, economic, or moral, rationale." ${ }^{42}$

\section{Strategic Legal Argumentation and Its Consequences}

While commonly associated with forms of deliberation, the above account is also compatible with the strategic assumptions adopted in this article. An actor will seek to gain support for- or at least acquiescence to - its policy by reference to the most compelling constellation of claims it can muster. The particular authority that international law enjoys means that actors will prefer to

\footnotetext{
${ }^{40}$ Shirley V. Scott, 'International Law as Ideology: Theorizing the Relationship between International Law and International Politics', European Journal of International Law, 5:1 (1994), pp. 313-25.

${ }^{41}$ Antony Anghie, Imperialism, Sovereignty, and the Making of International Law (Cambridge: Cambridge University Press, 2007); Michael Byers and Georg Nolte (eds.), United States Hegemony and the Foundations of International Law (Cambridge; New York: Cambridge University Press, 2003).

${ }^{42}$ Scott and Ambler, 'Does Legality Really Matter?', p. 72.
} 
invoke legal claims in their diplomacy, and effective arguing must adhere as closely as possible to the prevailing interpretations of relevant law. Similarly, the target audience should assess competing claims on their merits, and the legal content of arguments will shape their reception; this is so even in the many instances where actor beliefs do not change during the argumentative episode. Law is by its nature inherently contested, but it is not infinitely malleable; at any given point in time, actors still operate in relation to the existing legal institutions even as they may seek to modify or replace them. Hence while actors enjoy considerable flexibility in choosing how to present their arguments, the range of possible claims is bounded by contemporary legal practice.

Strategic legal argumentation proceeds via analogy, as parties attempt to justify their particular arguments by linking them to widely accepted standards operating at two different levels of generality. First, actors may invoke specific legal rules, whether found in a treaty or other source. The relative precision of legal texts may increase their impact in argumentative episodes, since they tend to permit a more limited scope for interpretation and deviation. ${ }^{43}$ Yet reference to rules in isolation is often insufficient to provide definitive answers concerning the meaning and limits of law. For this reason, actors will typically seek to further root their claims in a second set of higher-order norms spanning an array of concerns relating to conceptions of appropriate action (e.g., ending impunity for grave crimes), status (e.g., equality under law) and the nature of legal obligation itself (e.g., voluntary consent as the basis of adopting commitments). The existence of multiple sources of authority does not eliminate interpretive dilemmas, therefore, but the structure of international law provides an agreed framework through which the pursuit of policy goals via principled arguments can take place.

${ }^{43}$ Beth Simmons, 'Treaty Compliance and Violation', Annual Review of Political Science, 13:1 (2010), p. 277. 
Material power is never absent in international politics, but when deployed within a legal setting it is transformed, leading to outcomes that are substantially different from those that would be expected if law were mere "cheap talk." The move to a legal setting can empower weaker actors to overcome structural disparities by advancing more authoritative arguments in an environment in which forms of coercive force have receded ${ }^{44}$ At the same time, because rules are embedded within the extensive network of social practice, they provide a resource that may be exploited by states that are not formal members. But by invoking rules-even those they do not officially endorse - in an effort to advance their own narrow self-interest, resistant states are simultaneously drawn into debates about the scope of these institutions and may then be challenged on the validity of their interpretation concerning what a given rule permits or forbids. These factual disagreements may be further parlayed into claims of hypocrisy-in effect pointing out discrepancies between an actor's rhetoric and behaviour that undercut its purported good faith application of the law-leading to increasing social pressures to comply with the new standard. In other words, while non-parties may avoid the binding legal effect of new rules, they are never able to fully isolate themselves from these developments, and attempts to instrumentalize the law can generate unintended consequences that are difficult to control.

The core claim of this article is thus presented in the form of a counterfactual, that without the constraining effects of legal discourse, the United States would have been able to leverage its preponderant material power advantages to gain concessions that much more closely adhered to its initial demands. ${ }^{45}$ Counterfactual analysis is an especially useful means of

\footnotetext{
${ }^{44}$ Deitelhoff and Müller, 'Theoretical Paradise - Empirically Lost?', p. 170-171; Johnstone, The Power of Deliberation, pp. 6-7; Risse, '"Let's Argue!"', pp. 21-22.

${ }^{45}$ I thank one of the anonymous reviewers for encouraging me to develop this point more explicitly, and for suggesting this framing of the counterfactual.
} 
adjudicating amongst an array of possibilities that cannot be observed directly. ${ }^{46}$ In establishing these scenarios, however, attention must be paid to selecting theoretically and logically coherent possibilities: the more closely proposed counterfactuals follow the actual flow of events, the greater their analytical leverage. This can be achieved by identifying critical points from which alternative historical pathways could plausibly have emerged. If strategic argumentation were operative therefore, we should expect to see public discourse increasingly coalesce around a set of specific statements relating to context-appropriate legal standards, and policy outcomes shift in favour of the more widely accepted position. This should occur largely irrespective of the distribution of material capabilities between interlocutors. By contrast, an alternative explanation emphasizing material power would expect the US to deploy forms of coercion-possibly in concert with arguments - to gain acquiescence to its policy goals without substantial concessions to its opponents. In this view, while legal rhetoric is one potential strategy a powerful state may employ, the back-and-forth of strategic claim making will not significantly alter either its goals or the outcome of the episode; more fundamental forms of power politics will always be decisive in driving international diplomacy. Hence a predominant power may invoke law as a smokescreen for its interests, but move to a legal sphere should not stop it from getting its way on its terms. ${ }^{47}$

\section{Strategic Legal Argumentation and the ICC}

\footnotetext{
${ }^{46}$ James D. Fearon, 'Counterfactuals and Hypothesis Testing in Political Science', World Politics, 43:2 (1991), pp. 169-95; Kathryn Sikkink, 'The Role of Consequences, Comparison and Counterfactuals in Constructivist Ethical Thought', in Richard Price (ed.), Moral Limit and Possibility in World Politics (Cambridge; New York: Cambridge University Press, 2008), pp. 83-111.

${ }^{47}$ Glennon, Limits of Law, Prerogatives of Power; Goldsmith and Posner, The Limits of International Law.
} 


\section{Background}

The ICC is the first permanent international court aimed at investigating and prosecuting individual human beings for acts of atrocity, and thus reinforces a recent expansion of international law to include individuals as subjects of criminal responsibility and punishment. ${ }^{48}$ The Rome Statute reverses established diplomatic norms by removing the protected legal status of Heads of State and other high officials, ${ }^{49}$ and further adopts two forms of jurisdiction that apply to crimes committed by the nationals of a State Party in any geographic location, or by the citizens of any state on the territory of a State Party. ${ }^{50}$ While stopping short of permitting universal jurisdiction therefore, the Statute leaves open the possibility that nationals from nonparties may be subject to ICC prosecution even though their governments do not accept the Court's authority. This jurisdictional structure has been strongly resisted by the US and other prominent Court opponents on the grounds that it violates the foundational tenet that legal obligations may not bind third (non-party) states. ${ }^{51}$ The Rome Statute also gives the Prosecutor the power to initiate investigations proprio motu - that is, under his or her own initiative. ${ }^{52}$ This

${ }^{48}$ Kathryn Sikkink, The Justice Cascade: How Human Rights Prosecutions Are Changing World Politics (New York: W. W. Norton \& Company, 2011).

${ }^{49}$ Rome Statute of the International Criminal Court, 1998, Article 21.1, http://untreaty.un.org/cod/icc/statute/romefra.htm; Paola Gaeta, 'Official Capacity and Immunities', in Antonio Cassese, Paola Gaeta, and John R.W.D. Jones (eds.), The Rome Statute of the International Criminal Court: A Commentary, vol. 1 (Oxford: Oxford University Press, 2002), pp. 975-1002.

${ }^{50}$ Rome Statute, Article 12.2; Stephane Bourgon, 'Jurisdiction Ratione Loci,' in Antonio Cassese, Paola Gaeta, and John R.W.D. Jones (eds.), The Rome Statute of the International Criminal Court: A Commentary, vol. 1 (Oxford: Oxford University Press, 2002), pp. 559-69.

${ }^{51}$ Vienna Convention on the Law of Treaties, 1969, Article 34, https://treaties.un.org/doc/Publication/UNTS/Volume\%201155/volume-1155-I-18232English.pdf.

${ }^{52}$ Rome Statute, Article 15. 
goes against the demands of the US and others that the right to launch proceedings would be vested with the UNSC, giving the Council effective control over the Court's operation. ${ }^{53}$

Yet this legal regime is complicated by the fact that the Rome Statute provides mechanisms for limiting its own application. First, the Statute incorporates, in Article 98, the established international practice of granting legal exemption to representatives of other states for acts that would normally fall within the jurisdiction of the foreign host. Second and more important for the present analysis, Article 16 of the Statute permits the UN Security Council, acting under its Chapter VII authority, to request that the Court suspend an active investigation or trial for a renewable period of one year. These provisions attempt to strike a delicate balance between promoting international justice while acknowledging the importance of principles of state sovereignty and non-interference underpinning the international political order. ${ }^{54}$ Yet the implications of these legal innovations are far from settled, and differing views remain concerning the extent to which a UNSC resolution would bind the Court and thereby alter the operations of an independent international organization. ${ }^{55}$ For this reason, the strategic positioning of claims hinged on competing assertions concerning the scope of Article 16 - under what conditions the UNSC could limit the Court's jurisdiction — and by extension the manner in which the ICC related to other features of the international legal order.

${ }^{53}$ William A. Schabas, 'United States Hostility to the International Criminal Court: It's All About the Security Council', European Journal of International Law, 15:4 (2004), pp. 701-20; David Wippman, 'The International Criminal Court', in Christian Reus-Smit (ed.), The Politics of International Law (Cambridge: Cambridge University Press, 2004), pp. 166-174.

${ }^{54}$ Dapo Akande, 'International Law Immunities and the International Criminal Court', The American Journal of International Law, 98:3 (2004), pp. 407-33; William Schabas, An Introduction to the International Criminal Court, 4th ed. (Cambridge: Cambridge University Press, 2011), p. 183.

${ }^{55}$ Neha Jain, 'A Separate Law for Peacekeepers : The Clash between the Security Council and the International Criminal Court', European Journal of International Law, 16:2 (2005), pp. 23954; Carsten Stahn, 'The Ambiguities of Security Council Resolution 1422 (2002)', European Journal of International Law, 14:1 (2003), pp. 85-104. 


\section{Security Council Politics and the Immunities Debate}

To assess the dynamics of strategic legal argumentation, I focus on a series of debates in the Security Council over the renewal of the UN peacekeeping mission in Bosnia and Herzegovina (UNMIBH). The meetings over UNMIBH came at a particularly sensitive moment in the consolidation of the ICC, and emerged as a focal point in the shifting US strategy towards the Court. While the United States had long harboured serious reservations, these objections transformed into overt hostility only once it became clear that the ICC would soon become operational with the entry into force of the Rome Statute on July 1, 2002. To that end, US representatives sought to secure binding Security Council resolutions that would provide permanent exemptions from ICC jurisdiction for military and police forces drawn from non-ICC member states deployed on UN-sanctioned operations.

A large number of states participated in the discussions as Council members or invited observers; extensive data thus exists concerning the US view and international responses. ${ }^{56}$ Moreover, the UNSC is recognized as a primary setting for the enactment of bargaining, argumentation and deliberation. ${ }^{57}$ Indeed, the meetings in question were explicitly identified by a number of delegations as a forum in which to debate appropriate responses and seek a reasoned consensus on extent of immunities and the nature of the relationship between the ICC and UN system. While such statements imply a measure of flexibility and willingness to be persuaded, it

\footnotetext{
${ }^{56}$ In addition to the usual 15 members, a further 25 states attended the debate over Resolution 1422 (2002); additionally, Costa Rica spoke on behalf of the other 17 members of the Rio Group, while Denmark spoke on behalf of the 15 members of the European Union plus 13 affiliated states. In the subsequent 2003 debate over Resolution 1487, 18 observer delegations attended, while Greece represented the EU plus 14 affiliated states, and Peru represented the Rio Group. ${ }^{57}$ Johnstone, 'Security Council Deliberations'; Erik Voeten, 'Outside Options and the Logic of Security Council Action', American Political Science Review, 95:4 (2001), pp. 845-58.
} 
was understood at the time that underlying views were unlikely to change. The principal lines of debate thus focused on two main perspectives: that of the United States in seeking to gain acceptance for its immunities policy on the one hand, and that of the majority of participating states seeking to resist this effort (and thus support the status quo in the Rome Statute), on the other. Hence, the resulting interactions are most appropriately conceived as strategic attempts to convince the other side to accept the inevitability of an outcome without changing minds.

Finally, the Security Council is suffused with power politics and structural inequality, and is an ideal setting in which to explore the interaction of coercive and argumentative modes of influence. It is therefore not surprising that the United States sought to leverage its privileged position within the UNSC to advance its goal of a global exemption from ICC jurisdiction. The US initiatives were explicitly linked to continued participation peacekeeping operations - in other words, a threat of material punishment. US diplomats first attempted unsuccessfully to incorporate an immunity provision into the May 2002 establishment of a UN peacekeeping mission in East Timor; when this failed, the US promptly withdrew its forces from the mission. ${ }^{58}$ The stakes were much greater in the case of the UN Mission in Bosnia, which constituted one of the largest UN operations. As a State Party to the Rome Statute, alleged crimes committed on Bosnian territory by the national of any state would be subject to potential ICC jurisdiction, including the approximately 8000 US service members deployed as part of UNMIBH and associated NATO-led Stabilization Force (SFOR) ${ }^{59}$ Officials made clear that the United States

\footnotetext{
${ }^{58}$ Statement by US representative, June 30 2002. At the time, the United States had three military observers and approximately 80 police officers deployed to the UN mission Colum Lynch, 'US Seeks Court Immunity For East Timor Peacekeepers', The Washington Post (16 May 2002), http://www.globalpolicy.org/component/content/article/199/41050.html.

${ }^{59}$ Yet as Schabas points out, the US approach was not motivated by a particular threat of legal exposure in Bosnia, but concerned the potential application of ICC jurisdiction to American
} 
would continue to block future resolutions that did not contain the desired immunity provision, and would withdraw their forces from those UN operations that did not enjoy suitable exemptions from ICC jurisdiction. Moreover, officials threatened to withhold the US's 25\% share of the UN peacekeeping operations budget should their demands go unheeded.

Diplomacy at the Security Council must also be situated within a wider US policy of seeking global indemnity from the Court through a web of bilateral non-surrender agreements. These agreements - in which third party states agreed not to turn US service members over to the ICC — were negotiated via threats and incentives, as US law required that military aid and economic assistance be suspended to any states that refused to conclude a non-surrender arrangement. ${ }^{60}$ Hence, coercive tactics featured prominently in the US approach both inside and outside the Security Council, and ICC supporters faced real material costs in resisting US pressure. This generated a dilemma of whether to persist with their prior commitment to the ICC or concede to American demands, making the episode a key early test case for the US immunities strategy and the international response.

Strategic Legal Argumentation in Motion: Resolutions 1422 and 1487

The United States initially proposed language to amend the re-authorization of the UNMIBH mission that would have absolved US forces in perpetuity for acts committed as part of UN

officials in more controversial military settings. Schabas, An Introduction to the International Criminal Court, pp. 780-781.

${ }^{60}$ Judith Kelley, 'Who Keeps International Commitments and Why? The International Criminal Court and Bilateral Nonsurrender Agreements', The American Political Science Review, 101:3 (2007), pp. 573-89; Jason Ralph, Defending the Society of States Why America Opposes the International Criminal Court and Its Vision of World Society (Oxford: Oxford University Press, 2007), pp. 156-163; Schabas, An Introduction to the International Criminal Court, pp. 781-782. 
operations in Bosnia. ${ }^{61}$ The core thrust of the US position relied on political claims concerning the primacy of state sovereignty and its special role as a global military power.

Contributing personnel to peacekeeping efforts demonstrates a commitment to international peace and security that, as you all know, can involve hardship and danger to those involved in peacekeeping. Having accepted these risks by exposing people to dangerous and difficult situations in the service of promoting peace and stability, we will not ask them to accept the additional risk of politicized prosecutions before a court whose jurisdiction over our people the Government of the United States does not accept. ${ }^{62}$

In so doing, the US delegation only made passing reference to the prevailing legal context, highlighting immunity provisions in previous status of forces agreements and briefly asserting that Article 98 of the Rome Statute generically accommodated this practice. ${ }^{63}$

The response from other UNSC members begins to demonstrate the analytical purchase of the strategic legal argumentation frame. Rather than conceding to US coercion at this early stage, ICC proponents instead offered a counter-proposal (attributed to France) that specifically invoked Article 16 of the Rome Statute, limiting prospective deferrals of ICC investigations or prosecutions 'on a case by case basis'." While this concession could be read as an effort to reach

${ }^{61}$ The relevant passage of the US draft proposal of 19 June 2002 reads: "Decides that persons of or from contributing states acting in connection with such operations shall enjoy in the territory of all Member States other than the contributing State immunity from arrest, detention, and prosecution with respect to all acts arising out of the operation and that this immunity shall continue after termination of their participation in the operation for all such acts." After nearuniversal opposition - owing to the fact that the language also exempted individuals from the criminal jurisdiction of the International Criminal Tribunal for the Former Yugoslavia - the US subsequently modified the language in a second proposed draft text of June 27 that specified the exemption applied only to "current and former officials and personnel from a contributing State not a party to the Rome Statute" and did not modify the existing legal standing of the ICTY. This episode constitutes an initial, though comparatively minor, concession since the US still sought permanent immunity for its own forces. Reference to this and other draft documents cited in this section can be found in Coalition for the International Criminal Court, Compilation of Documents on UN Security Council Resolutions 1422/1487 (New York, May 2004), http://www.iccnow.org/documents/1422DocumentCompilation.pdf.

${ }^{62}$ Statement by the United States of America to the United Nations Security Council. 4563rd meeting. Agenda Item: The situation in Bosnia and Herzegovina. New York. 30 June 2002. http://www.un.org/en/sc/meetings/.

${ }^{63}$ See preamble paragraph 3 of the 19 June 2002 draft proposal. 
an acceptable position via a convergence of views — as accounts of bargaining would suggest — it is more properly understood as a strategic attempt to shift the diplomatic discourse onto the more favourable (for ICC proponents) legalized terrain of the Rome Statute. This move to a legal mode of argumentation substantially influenced the resulting diplomacy by narrowing the range of acceptable claims in subsequent debates. The United States initially persisted with its position, and when its effort failed to gain sufficient support within the Council the US vetoed the resulting draft resolution that excluded an immunity provision. ${ }^{64}$ This episode was significant, however, as it marked the turning point where the Rome Statute — and especially Article 16now became the primary reference point for effective strategic appeals.

The defeat led the US to change its approach, and American diplomats adopted an explicitly legal mode of argumentation. The demand for an effectively blanket immunity from ICC prosecution was now premised on a claim that as a non-party, the United States had no legal obligations under the Rome Statute, and US nationals should therefore not be subject to ICC jurisdiction through its participation in UN operations. For the first time, the US also took pains to couch their claims in the more precise terms of the Rome Statute, arguing that Article 16 permitted the exemptions they were seeking, and was consistent with the Security Council's primary role in upholding international peace and security. ${ }^{65}$ US diplomats consequently introduced a new draft proposal that referenced Article 16 but simultaneously retained a quasipermanent exemption since the immunity provision would be automatically renewed annually

\footnotetext{
${ }^{64}$ UN S/PV.4563, 30 June 2002. The draft text (S/2002/712) is available at http://www.un.org/en/ga/search/view_doc.asp?symbol=S/2002/712. The vote was 13 in favour, with the United States voting against and Bulgaria abstaining. ${ }^{65}$ Statement by the United States of America to the United Nations Security Council. 4568th meeting. Agenda Item: The situation in Bosnia and Herzegovina. New York. 10 July 2002. http://www.un.org/en/sc/meetings/.
} 
"unless the Security Council decides otherwise." ${ }^{66}$ This change can be understood as a strategic attempt to present the US position in terms that would be more acceptable to its audience - in other words, an effort to instrumentalize the justificatory language of law to serve pre-established policy goals.

This effort did not result in an immediate concession as US representatives expected. The vast majority of states speaking at the meeting challenged to the US initiative through a discursive strategy that invoked both the specific legal criteria of the Rome Statute as well as broader principles of international law. ${ }^{67}$ First, they argued that the Statute already contained sufficient procedural checks and balances to effectively eliminate US concerns for politically motivated prosecutions. ${ }^{68}$ Second and more fundamentally, it was claimed that contrary to American assertions, the proposal for granting a priori immunity expressly violated the terms of Article 16 both because it envisioned an effectively permanent exemption irrespective of an ongoing ICC legal process and because it reversed the intention that renewal be done by an affirmative vote of the Council.

[T] he proposals now circulating would have the Council, Lewis-Carroll-like, stand article 16 of the Rome Statute on its head. The negotiating history makes clear that recourse to article 16 is on a case-by-case basis only, where a particular situation-for example the dynamic of a peace negotiation - warrants a 12-month deferral. The Council should not purport to alter that fundamental provision. ${ }^{69}$

\footnotetext{
${ }^{66}$ Operative paragraph 2 of the US draft proposal of 1 July 2002.

${ }^{67}$ In total, 77 voiced opposition to the US proposal at the 2002 Security Council meeting. 32 states made statements, including Costa Rica speaking on behalf of the Rio Group, and Denmark speaking on behalf of the EU and 13 associated states. The full records are available via United Nations Security Council. 4568th meeting, and Resumption 1. Agenda Item: The situation in Bosnia and Herzegovina. New York. 10 July 2002. http://www.un.org/en/sc/meetings/.

${ }^{68}$ Statements by Bosnia and Herzegovina, Brazil, Canada, Colombia, Costa Rica, Denmark, Fiji, France, Guinea, Ireland, Jordan, Liechtenstein, Malaysia, Mauritius, Mexico, Mongolia, New Zealand, Norway, Samoa, Sierra Leone, Switzerland, Syria and United Kingdom. United Nations Security Council, 10 July 2002.

${ }^{69}$ Statement by Canada. United Nations Security Council, 10 July 2002.
} 
The language of the draft resolution — and hence the centrepiece of the US legal claim—was thus considered by most ICC parties to be fundamentally incompatible with the letter and intent of the Statute and hence contrary to objective of the Court. ${ }^{70}$ Finally, ICC proponents contended that the US position equating the international prosecution of citizens with a violation of state consent (the third party effect of treaties) was a misinterpretation of established law. Indeed, a variety of international treaties concerning torture, terrorism and hijacking already permit extra-national jurisdiction for individuals without their home state's approval, yet this does not amount to a legally binding obligation on the state itself. ${ }^{71}$ In light of this, a host of ICC proponents suggested that adoption of the proposed Resolution would pose a threat to the integrity of the Rome Statute itself by placing unjustified burdens on the operation of the Court. ${ }^{72}$

Yet the arguments also transcended the particular content of the Rome Statute to encompass more fundamental claims of legal equality and respect for norms regulating the modification of international legal instruments. On the one hand, the attempt to exempt an entire category of individuals — peacekeepers and affiliated personnel—was described as "enshrin[ing] an unconscionable double standard." ${ }^{13}$ On the other hand, numerous countries argued that the US demand would set a precedent for the Security Council to unilaterally re-interpret existing multilateral agreements without the approval of the treaty parties, a power not envisioned in the

\footnotetext{
${ }^{70}$ Statements by Brazil, Canada, Costa Rica (on behalf of the Rio Group), Denmark (on behalf of the EU and associated states), Liechtenstein, Mauritius, Mexico, New Zealand, Samoa and Switzerland. United Nations Security Council, 10 July 2002.

${ }^{71}$ Wippman, 'The International Criminal Court', pp. 155 and 172-173.

${ }^{72}$ Statements by Argentina, Costa Rica (on behalf of the Rio Group), Denmark (on behalf of the EU and associated states), Fiji, Liechtenstein, Mexico, New Zealand, Samoa, Thailand, Ukraine and Venezuela. United Nations Security Council, 10 July 2002.

${ }^{73}$ Statement by New Zealand. United Nations Security Council, 10 July 2002.
} 
UN Charter. ${ }^{74}$ Such an outcome, it was held, would force State Parties to violate their legal obligations under the Statute, and undercut the sovereign right of states to undertake binding legal commitments. The US proposal was thus portrayed as an extra-legal interference in the treaty making process, and an overreach of Security Council authority "that would destabilize and undermine the international legal regime" based on the principle of sovereign equality and the sanctity of legal agreements. ${ }^{75}$ This, in turn, could only serve to degrade the credibility of the Security Council by further politicizing its decisions. ${ }^{76}$

Finally, delegates attempted to leverage US support for the International Criminal Tribunal for the Former Yugoslavia into a claim of inconsistency to further challenge the validity of the US position. They pointed out that the ICTY retained jurisdiction over all alleged crimes committed in Bosnia, so the concern regarding ICC authority was misplaced. ${ }^{77}$ But more fundamentally, if the US was satisfied with ceding authority—including, potentially, over its own soldiers - to one supra-national court, how could it justify its virulent opposition to the ICC? This rhetorical move conveniently neglected the fact that the ICTY was created by a UNSC resolution and thus remained (though at arms length) under its purview, which was precisely why the US could countenance the Tribunal. The strategic positioning of this claim was therefore not intended to advance a reasoned process of truth-seeking leading to a convergence

\footnotetext{
${ }^{74}$ Statements by Brazil, Canada, Colombia, Costa Rica (on behalf of the Rio Group), Cuba, Fiji, Germany, Guinea, Iran, Jordan, Malaysia, Mauritius, Mexico, New Zealand, Samoa, South Africa, Switzerland, Syria, Thailand, Ukraine, United Kingdom and Venezuela. United Nations Security Council, 10 July 2002.

${ }^{75}$ Statement by Syria. United Nations Security Council, 10 July 2002. Statements by Canada, Colombia, Costa Rica (on behalf of the Rio Group), Germany, Jordan, Liechtenstein, New Zealand, Samoa, Syria, Ukraine and Venezuela. United Nations Security Council, 10 July 2002. ${ }^{76}$ Statements by Argentina, Brazil, Canada, Costa Rica (on behalf of the Rio Group), Fiji, France, Germany, Ireland, Liechtenstein, Malaysia, New Zealand and Ukraine. United Nations Security Council, 10 July 2002.

77 Schabas, An Introduction to the International Criminal Court, pp. 780-781; Stahn, 'The Ambiguities of Security Council Resolution 1422 (2002)', pp. 86-87.
} 
of views, but instead to further box the US into a socially unsustainable position. Irrespective of this deliberate oversight, charges of hypocrisy forced US representatives into further defence of their proposal that later proved consequential in limiting US policy options. The most obvious rejoinder - that the US only accepted international justice when it could control the outcomes via its Security Council veto-was politically undesirable as it was obviously unlikely to appeal to the majority of ICC supporters.

Despite the stakes and apparent vehement opposition from the majority of participating states, Resolution 1422 was approved by a unanimous vote. A sceptical reading would suggestas per the alternative explanation to this study — that international law served merely as a convenient forum for airing grievances, but did not ultimately affect the policy outcome sought by the most powerful actor. ${ }^{78}$ Undoubtedly Resolution 1422 was passed under extreme duress as the US employed extensive coercion in the form of prospective sanctions (the withdrawal of US forces and funding from UN operations) to gain acquiescence to its demands. Yet an emphasis on material power in isolation fails to appreciate the extent to which the shift into legal argumentation constrained US options in pursuing its global immunities policy. First, ICC supporters could have simply accepted the initial US proposal in order to avoid the prospect of substantial punishment. Yet the overwhelming majority of states instead chose to challenge US policy through an alternative assemblage of legal arguments anchored around Rome Statute Article 16. This strategic reframing occasioned a shift in emphasis to the legal criteria of the Statute itself, thereby drawing the US into a debate on the terms of an institution it openly opposed.

\footnotetext{
${ }^{78}$ Glennon, Limits of Law, Prerogatives of Power; Goldsmith and Posner, The Limits of International Law.
} 
Second and relatedly, the opposition faced within the Security Council compelled the United States delegation to hew more closely to the wording of Article 16, which in turn implied substantial concessions limiting the impact of the exemption. Recall that the US initially sought permanent immunity for all nationals deployed in the Bosnian peacekeeping missions. The US draft text thus included an effectively automatic annual renewal, since cancellation was subject to an affirmative Security Council vote in which the US held veto power. ${ }^{79}$ At the same time, the initial US proposal employed the more authoritative formulation of "decides" that is typical of Chapter VII resolutions; this was meant to underscore the pre-eminence of the Council in requiring the Court to defer any future investigation relating to non-party nationals. Yet at the insistence of pro-ICC states, Resolution 1422 authorized only a more modest one-year exemption that could be renewed via a further resolution and incorporated Article 16's use of "requests" vis-à-vis the Council and Court. These were significant modifications since they placed the US demand under regular scrutiny, ensuring that representatives would have to continue to engage in public justifications on the terms of the Rome Statute. The US concession was made necessary by the institutional context of the Security Council and the requirement of nine affirmative votes (and no vetoes from permanent members); yet the particular content of the final resolution was profoundly shaped by the prior argumentation in which the initial US claim failed to out-manoeuvre the contending position. The successful attempt by ICC supporters to bring UNSC 1422 under the aegis of Article 16 thus shifted the balance between claimants, deemphasizing the US demand that the Security Council should dominate the Court in favour of greater equity between two independent bodies and consequently restraining the exercise of US power.

\footnotetext{
${ }^{79}$ Ralph, Defending the Society of States, p. 165; Stahn, 'The Ambiguities of Security Council Resolution 1422 (2002)', pp. 85 and 101.
} 
Finally, while the US strategy of combining coercion and argumentation did yield some success, it also had the unintended consequence of reinforcing the move to a legal discourse that did not favour the US position over the long term. The diplomatic record demonstrates that ICC supporters assessed the US initiative on the merits, and thus employed legal criteria as an alternative source of legitimate authority in deciding on the content of the resolution. Only three states - China, India and Russia — endorsed the content of the US position in the Council discussions before voting was held on the 2002 draft resolution. This is contrasted with 32 states, including two speaking on behalf of major regional organizations, which did not accept that the resolution accurately reflected the letter or intent of the Rome Statute. While the American shift to legal arguments did not change minds, the deference to a legal framing was crucial in strategic terms as it provided other states with the minimally acceptable grounds required to justify their temporary yielding to US demands, even though the decision was motivated by other concerns. This is the essence of the strategic account advanced here. At the same time, such discursive moves are "sticky" in the sense that once activated they are difficult to abandon, a fact that would prove highly relevant to subsequent developments.

One year later, the United States was able to secure a further one-year extension of the UNMIBH immunity provision with the approval of Resolution $1487 .{ }^{80}$ Here again there was little acceptance of the US view, as the overwhelming majority of states spoke against the resolution. ${ }^{81}$ The modes of argumentation followed a similar form, though with some important changes that hold implications for the integrity of the ICC. The US again argued that the resolution was compatible with the Rome Statute and the fundamental principles of consent and

${ }^{80}$ UNSC 1487 was passed with 12 votes in favour and three abstentions (France, Germany and Syria).

${ }^{81}$ Only Pakistan offered explicit endorsement while Angola, Bulgaria, China and the Russian Federation made more general statements of understanding. 
the limit of third party effects in international law. Yet the American representative also sought to challenge the Court's legitimacy through an invocation of the constitutive structures of the international system. The reading of Article 16 advocated by ICC proponents would "challeng[e] and weak[en] the United Nations Charter system and the Council's place in it;" ${ }^{82}$ the US interpretation, by contrast, was presented as returning the UNSC to its appropriate position of primacy. The US also revisited the theme of peace and security, and argued that the spectre of ICC jurisdiction — without the limits provided in Resolutions 1422 and 1487—could have a chilling effect on the future efficacy of UN peacekeeping operations by imperilling the participation of non-ICC members.

Supporters of the Court again contested the US position on largely the same legal grounds, by reiterating the Rome Statute's safeguards against politicized prosecutions, ${ }^{83}$ and challenging the US interpretation of Article 16 of the Rome Statute ${ }^{84}$ and its resulting implication concerning the Security Council's role in interpreting multilateral treaties. ${ }^{85}$ As such, the majority of the Council again found that the US demands were inconsistent with the Rome Statute, UN Charter, and more fundamental principles of international law. Finally, Court proponents invoked a new claim that Resolution 1487 and its predecessor were context-specific and temporary exceptions that did not constitute a legal or political precedent for future

\footnotetext{
${ }^{82}$ Statement by the United States of America to the United Nations Security Council. 4772nd meeting. Agenda Item: United Nations Peacekeeping. New York. 12 June 2003. http://www.un.org/en/sc/meetings/

${ }^{83}$ Statements by Argentina, Brazil, Canada, France, Germany, Greece (on behalf of the EU and associated states), Guinea, Iran, Liechtenstein, New Zealand, Nigeria, Switzerland, Syria, Trinidad and Tobago and Uruguay. United Nations Security Council, 12 June 2003. ${ }^{84}$ Statements by Greece (on behalf of the EU and associated states), Jordan, Liechtenstein, Netherlands, New Zealand, Nigeria, Switzerland and Trinidad and Tobago. United Nations Security Council, 12 June 2003.

${ }^{85}$ Statements by Brazil, Canada, Germany, Iran, Jordan, Liechtenstein, New Zealand, Pakistan, Switzerland and Trinidad and Tobago. United Nations Security Council, 12 June 2003.
} 
exemptions. ${ }^{86}$ The statements made particular reference to the exceptional circumstances and noted that the annual renewals should not be regarded as automatic or pre-determined. Hence the immunity provision was not normalized even as the international system's highest political body again conceded to US pressure.

The successful limits placed on US policy would prove highly consequential the following year, as the Security Council again deliberated a renewal of the UN mission in Bosnia and with it, the contested exemption of US personnel. Yet in the intervening period, a series of revelations concerning American policies in the War on Terror undercut the US negotiating position. In particular, the release of photographs documenting serious abuses at Abu Ghraib Prison in Iraq drew widespread condemnation, and further increased scrutiny on US efforts at the Security Council. In light of this, the United States announced that it would not seek a further renewal immunity provision as a precondition for approving the extension of UN operations in Bosnia. In doing so, US representatives indicated that while they had not changed their views regarding the ICC, they equally recognized that members of the Council were no longer willing to support their demands. ${ }^{87}$ This reversal cannot be adequately explained solely in reference to changes in external conditions. Legal protections for US nationals remained an active concern: by 2004 roughly 1000 American military personnel were deployed in Bosnia as part of the

\footnotetext{
${ }^{86}$ Statements by Angola, Canada, France, Greece (on behalf of the EU and associated states), Guinea, Iran, Liechtenstein, Malawi, Netherlands, Peru (on behalf of the Rio Group), South Africa, Spain, Switzerland and the United Kingdom. United Nations Security Council, 12 June 2003.

${ }^{87}$ Richard Boucher, 'Department of State Daily Press Briefing' (Washington, DC, 23 June 2004), www.amicc.org/icc/peacekeeping.
} 
NATO-led Stabilization Force (SFOR) and hence the value of a further Security Council resolution had not abated. ${ }^{88}$

Rather, the US decision can only be understood by taking into account the social context of diplomacy and especially the legal criteria that informed successful strategic argumentation. While global publicity surrounding US abuses undoubtedly weakened the US negotiating position, this development was consequential not instead, but because of the interconnected nature of legal reasoning and justification. The United States had sought to oppose the ICC jurisdictional regime on the grounds that it did not accord with established international law. Yet conduct in Iraq and elsewhere exposed widespread human rights violations that undermined the credibility of US claims to good faith respect for the law. Other states were consequently even less inclined to conditionally accept US interpretations in the Bosnia case, precisely because the immunities issue was assessed in the context of a wider international law discourse. It was in this sense that the subsequently revealed hypocrisy proved politically consequential: as external events reinforced the legal basis informing judgements over American immunities policy, the social costs associated with its continuation became intolerable. Yet this was only relevant because previous manoeuvres by the pro-ICC constituency had already successfully limited the immunities provision to annual non-automatic renewals. The decision not to further extend the resolution in 2004 is therefore crucial, since it prevented the substantiation of the US position as a fait accompli. ${ }^{89}$

\footnotetext{
${ }^{88}$ Schabas, An Introduction to the International Criminal Court, p. 780. Julie Kim, Bosnia and the European Union Military Force (EUFOR): Post-NATO Peacekeeping, CRS Report to Congress (Washington, DC: Congressional Research Service, 5 December 2006), p. 2 , www.fas.org/sgp/crs/row/RS21774.pdf.

${ }^{89}$ Stahn, 'The Ambiguities of Security Council Resolution 1422 (2002)', p. 104.
} 
Had US coercive power been sufficient on its own, we would expect the international community to continue its begrudging acceptance of US demands for special exemption from ICC jurisdiction even if the principled case became less favourable. Instead, the decision to deploy legal argumentation in the pursuit of its immunities objective had the unanticipated consequence of boxing the US into a defence of its policy on specific grounds from which it subsequently found it difficult to extract itself. When the widening gap between words and deeds became apparent, the US had little room for rhetorical manoeuvre. Put differently, strategic argumentation by pro-ICC constituency made the political conditions inhospitable for the US position, and the United States consequently altered its policy in order to avoid additional diplomatic damage.

\section{Subsequent Developments}

More recent developments within the Security Council have continued the debate over US immunity policy. Successive resolutions creating a UN peacekeeping force Liberia and referring the situations in Darfur and Libya to the ICC Prosecutor have contained an operative clause that provides a permanent exemption for nationals of non-party states from ICC jurisdiction. ${ }^{90}$ This was regarded by American representatives as legal affirmation of their previous position and a precedent for future deliberations. ${ }^{91}$ The debate in these three cases largely mirrored the discourse surrounding Resolutions 1422 and 1487, raising the question as to whether the United

\footnotetext{
${ }^{90}$ United Nations Security Council Resolution 1497, operative paragraph 7. Parallel language can be found in the Resolution 1593 and Resolution 1970. http://www.un.org/en/sc/documents/resolutions/.

${ }^{91}$ Statement by the United States of America to the United Nations Security Council. $5158^{\text {th }}$ meeting. Agenda Item: Reports of the Secretary-General on the Sudan. New York. 31 March 2005. http://www.un.org/en/sc/meetings/.
} 
States has succeeded in manoeuvring other states into a de facto acknowledgement of a permanent non-party exemption from the ICC.

Subsequent discourse reveals a mixed picture, but one in which the US strategy has failed to fundamentally alter international practice regarding immunities. As in the Bosnia case, ICC proponents again accepted the US demand on the grounds that its negative implications were outweighed by the immediate necessity of addressing ongoing violence in Liberia, Sudan and Libya. ${ }^{92}$ The inclusion of an immunity provision was therefore due to the combined effect of material threats and the inclusion of minimally acceptable legal language that provided a pretext for the concession. A number of delegations thus explicitly asserted that their approval of the resolutions did not represent a precedent for future situations, despite US assertions to the contrary. ${ }^{93}$ Yet the evidence equally does not support a view that US efforts have generated a sufficiently widespread or stable acceptance of its position as successful strategic argumentation would require. Since the immunities campaign began in 2002, there have been 217 UN Security Council resolutions authorizing or renewing peacekeeping operations; of that substantial list, only the five mentioned above contain provisions exempting non-party nationals, or UN personnel more broadly, from ICC jurisdiction. When considered in this light, the short-term concessions from pro-ICC states resemble isolated tactical accommodations rather than a genuine shift in the international status quo. And significantly for my theory, states have not been boxed into an unsustainable position by US efforts, but have rather continued to contest its policy on principled grounds. Given the enduring prevalence of coercion in US foreign policy

\footnotetext{
${ }^{92}$ Statements by France, Germany and Mexico, 1 August 2003; Argentina, Benin, France, Greece, Japan, Philippines and Tanzania, March 31 2005; and Bosnia and Herzegovina, Brazil and France, 26 February 2011.

${ }^{93}$ Statements by Argentina, Denmark, Tanzania. United Nations Security Council, 31 March 2005.
} 
more generally, this suggests that the strategic invocation of legal argumentation has limited the scope of US power and thus generated outcomes that are notably different than would be expected had material power trumped principled discourse.

Rather, US efforts have arguably had the inverse — and unintended — consequence of increasing the profile of the ICC as a competent feature of the international system. As Stahn has noted, "by pushing for the adoption of Resolution 1422 (2002) the US has incidentally recognized that the jurisdiction of the ICC extends to nationals of third states." 94 This had significant repercussions, as US representatives were increasingly subject to claims of hypocrisy in allowing other non-party nationals (in Sudan and Libya) to be subject to a Court from which they themselves were exempted. Legalized argumentation has thus led to a form of rhetorical entrapment that further undermined the prospects that the global audience of states will accept the US position. Recognition of the US failure to undermine the ICC immunities regime has compounded during the Obama administration, which has signalled a more open - though not fully supportive - approach to the Court and has clearly seen no political benefit in reviving its legal contestation. This in turn demonstrates the often subtle, but politically significant, role that legal rhetoric plays in shaping state policy.

\section{Conclusion: The Power of Legal Argumentation in World Politics}

Scholars have noted the prevalence of legal discourses in international relations, yet the impact of principled interventions remains a subject of considerable debate. This article contributes to theoretical conceptions of argumentation by highlighting the distinctive structure and effects of legal claim making, and provides empirical evidence to support its account through a close attention to diplomatic practices in a particularly challenging case. As anticipated by my theory,

\footnotetext{
${ }^{94}$ Stahn, 'The Ambiguities of Security Council Resolution 1422 (2002)', p. 94.
} 
legal standards served as a reservoir of legitimacy for actors to exploit in debates over the ICC immunities regime. Competing claims were positioned in relation to a set of legal principles that in turn conditioned the success or failure of policy efforts: most fundamentally, the United States was unable to manoeuvre other states into accepting its terms (and abandoning their own position) because its principled claims were not regarded as sufficiently compelling. Inversely, the strategic manoeuvring by ICC proponents generated political conditions in which the immunities campaign was no longer regarded as worth the political costs. The strategic employment of legal arguments thus contributed to political outcomes by increasing the social sustainability of certain policies and consequently diminishing that of others. The resulting accommodations emerged as a response to the political environment generated by these diplomatic episodes, and without changes in underlying beliefs.

This account does not contend that material power ceases to matter in a legal context, or that international law operates independent of political, economic and social forces in the international system. As the case study shows, the US deployed coercion alongside its discursive claims, and these tactics in combination did achieve a largely favourable outcome initially. Yet US material power-whether alone or in concert with argumentation - was not decisive in the immunities debates, as other states did not accept the full range of US demands despite extensive pressure. Rather, the adoption of an argumentative frame based in law transformed the resulting diplomacy in ways that the United States could not fully control and that ultimately led to outcomes that were successively further from the initial US position. The self-interested use of law thus cut both ways, as the strategy exposed US diplomats to countervailing arguments that progressively focused around an interpretation of how the ICC — especially in Article 16related to wider principles of criminal accountability and the role of the UNSC in global order. 
This foreclosed certain types of claims that could no longer be squared with these standards, thereby narrowing the range of subsequent policy options available to US diplomats.

Material resources were therefore constrained by the parameters of acceptable legal argumentation that in turn provided a resource for other, less powerful actors to counter US coercion via alternative claims and without corresponding material capabilities. ICC proponents successfully reconstructed the terms of the debate to emphasize the Rome Statute as the sine qua non for assessing an acceptable argument. In this specialized context, US claims were judged as not being sufficiently in conformance with the prevailing legal criteria by most states engaged in the discussions. This did not prevent concessions to US power in the form of Resolutions 1422 and 1487, but it did ensure both that the resolutions were more limited than American officials had demanded and that subsequent debates would continue to take place on the terms of the Rome Statute. Thus even a dominant military power like the United States can face consequences when its behaviour is judged to contradict community standards. These forms of constraint are a crucial part of the story that would be obscured if focusing on American material preponderance in isolation. In these respects the ICC has proven more resilient than many would have anticipated, and this is particularly surprising given the scepticism that the Court could exert influence in the face of sustained US pressure..$^{95}$

Finally, this study reinforces the constructivist intuition that social modes of power exist alongside material and instrumental forms that are more typically the interest of realist and institutionalist IR scholars. ${ }^{96}$ The shift to law valorizes principled justification and devalues claims based in naked self-interest or coercion. The invocation of legal claims thus tempers the

95 Jack Goldsmith, 'The Self-Defeating International Criminal Court', University of Chicago Law Review, 70:1 (2003), pp. 89-104.

${ }^{96}$ Barnett and Duvall, 'Power in International Politics'. 
use of threats or incentives, and the deployment of material power resources has different—and more modest — effects than it would outside an argumentative and especially legal context. Hence one important way that law matters in international relations is by providing an alternative environment in which the self-interested pursuit of policy goals may develop, which in turn sheds light on the power of legal argumentation in world politics. 